\title{
Carcinogenesis of Barrett's esophagus: a review of the clinical literature
}

\author{
Jiro Watari · Tadayuki Oshima $\cdot$ Hirokazu Fukui • \\ Toshihiko Tomita $\cdot$ Hiroto Miwa
}

Received: 21 July 2013/Accepted: 25 July 2013/Published online: 14 August 2013

(C) Springer Japan 2013

\begin{abstract}
Barrett's esophagus (BE) is a premalignant condition of esophageal adenocarcinoma (EAC). Although the incidence of $\mathrm{BE}$ has risen rapidly in the West, it is rare in Asia despite a recent increase in the prevalence of gastroesophageal reflux disease. Controversies over the definition of $\mathrm{BE}$ are presented because most cases show shortsegment BE, especially ultra-short BE, in Asia. Here we review possible risk factors for the development of EAC, particularly possible roles of ethnicity, specialized intestinal metaplasia (SIM), BE length, and environmental factors, such as Helicobacter pylori infection and obesity. Additionally, we summarize recent studies on the effect of chemoprevention including proton pump inhibitors, nonsteroidal anti-inflammatory drugs or aspirin in order to reduce the risk of neoplastic progression in BE patients. Although substantial knowledge of risk factors of dysplasia/EAC in BE is shown, the risk for neoplastic development may be influenced by geographic variation, study population, the presence or absence of SIM or dysplasia at baseline, and the small number of BE patients investigated. Recently, the efficiency of surveillance for BE patients has been discussed from the standpoint of cost-effectiveness. It may be too difficult to draw conclusions because no randomized clinical trials of $\mathrm{BE}$ surveillance have been performed.
\end{abstract}

J. Watari $(\bowtie) \cdot$ T. Oshima $\cdot$ H. Fukui · T. Tomita · H. Miwa Division of Upper Gastroenterology, Department of Internal Medicine, Hyogo College of Medicine, 1-1 Mukogawa-cho, Nishinomiya, Hyogo 663-8501, Japan

e-mail: watarij@hyo-med.ac.jp
Keywords Barrett's esophagus - Esophageal adenocarcinoma $\cdot$ Risk factors $\cdot$ Chemoprevention . Carcinogenesis

\section{Introduction}

Barrett's esophagus (BE) is a metaplastic condition where the normal squamous epithelium of the lower esophagus is replaced by metaplastic columnar epithelium [1]. From the histological viewpoint, $\mathrm{BE}$ includes a combination of three types of columnar epithelia described by Chandrasoma et al. as cardiac, oxyntocardiac, and intestinal [2]. Among these types, intestinal metaplastic mucosa, namely specialized intestinal mucosa (SIM), has been conventionally accepted as the only neoplastic precursor of esophageal adenocarcinoma (EAC) [3-5].

Although there may be a regional variation in the cancer risk among BE patients, it is generally considered that patients with $\mathrm{BE}$ have a 30 - to 125 -fold increase in the risk of developing adenocarcinoma, with an annual incidence rate of approximately $0.5 \%$ [6-8], and monitoring of $\mathrm{BE}$ patients for the development of adenocarcinoma is recommended at intervals of $2-3$ years $[1,9]$. Furthermore, many previous studies have reported that $\mathrm{BE}$ often progresses to EAC among male Caucasians in their 60s. Once an individual has been diagnosed as having $\mathrm{BE}$, management strategies such as appropriate surveillance, medical treatment, endoscopic ablative therapy, etc. are needed in order to reduce the risk of progression to EAC.

Here we review the causal factors of EAC and discuss efficient preventive strategies based on the clinical literature, with a focus on original contributions, systematic reviews, and meta-analyses. 


\section{Problems in the diagnosis of $\mathrm{BE}$}

Argument regarding landmark of esophagogastric junction in the BE definition

The identification of one or more landmarks that define the esophagogastric junction (EGJ) in the clinical diagnosis of $\mathrm{BE}$ is of great importance. The clinical diagnosis is based on the endoscopic recognition of red/pink gastric-like mucosa lining the tubular esophagus above the EGJ, which is defined as the most proximal margins of the gastric folds in the West (the Prague C \& M criteria) [10-12] and as the lower end of the palisade vessels of the lower esophagus in Japan (the Japanese criteria) [13-15]. In patients with severe atrophic gastritis, particularly Asian and Japanese individuals with Helicobacter pylori, the infection-which spreads through the cardia from the antrum-atrophic gastritis-makes it difficult for the oral end of the gastric folds to be used as a marker of the EGJ. However, Kinjo et al. [15] reported that the ratio of endoscopic BE diagnoses using the Japanese criteria was significantly higher than that using the Prague C \& M criteria in Japanese atrophic gastritis cases.

Amano et al. [14] showed that the upper end of the gastric folds as used in the Prague C \& M criteria may be a more suitable landmark than the palisade vessels for identifying the distal end of the esophagus by endoscopy in Japanese individuals. In their study, however, the coefficient stayed low ( $\kappa$ value $=0.35$ ) although the $\kappa$ coefficients of reliability in the diagnosis of $\mathrm{BE}$ improved markedly after an explanation of the Prague criteria for $\mathrm{BE}$ to the endoscopists involved. There is an interesting issue regarding whether American and Japanese endoscopists differ in their recognition of palisade vessels in various ethnic individuals. As a result, American and Japanese endoscopists similarly recognize the distal end of the palisade vessels as the EGJ ( $\kappa$ value $=0.88$ ) [16].

There are a few reports from the West in which the lower end of the palisade vessels is used as the landmark for the EGJ as in Japan [17-19]. An important disadvantage of considering the proximal ends of the gastric folds as the landmark for the EGJ is that the diagnostic concordance is very low, especially in ultra-short ( $<1 \mathrm{~cm}$ in length) and short-segment BE (SSBE), in which is difficult to detect this landmark. Chang et al. [20] demonstrated the utility of the Prague C \& M criteria to characterize BE in an ethnic Chinese population even though the BE was ultra-short $(<1 \mathrm{~cm})$; however, they did not mention the Japanese criteria. There is another problem in that insufficient extension and inadequate stretching of the lower esophagus, particularly under sedation, may disturb the identification of palisade vessels. Therefore, it is difficult to reach an international conclusion regarding the appropriate criteria to be used to identify the EGJ, Prague or Japanese, because both have drawbacks and advantages.

Clinical problems in the diagnosis of ultra-short BE $(<1 \mathrm{~cm}$ in length)

Many investigators have pointed out that the endoscopic diagnosis of ultra-short BE is difficult and highly unreliable [12, 21-23]. The overall reliability coefficients for the endoscopic recognition of $\mathrm{BE} \geq 1 \mathrm{~cm}$ was 0.72 , whereas for the endoscopic recognition of $\mathrm{BE}<1 \mathrm{~cm}$ of columnarlined epithelium (CLE), the coefficient was only 0.22 [12]. One possible reason for the difficulty may be the use of a different definition of the EGJ as discussed above [10-15]. In studies based in the USA, only cases in which SIM was histologically confirmed in CLE were defined as BE, of any length. In contrast, Japanese studies have reported that all CLE identified endoscopically is considered a sign of BE regardless of its length and the presence or absence of SIM on biopsy from CLE [13]. Some studies from Europe included patients without SIM in any length of CLE [24, $25]$.

However, ultra-short BE does not satisfy either American [9] or British [26] endoscopic requirements for the diagnosis of $\mathrm{BE}$, and several groups have contended that ultra-short BE should therefore not be given the name Barrett's esophagus [9, 19, 27]. In Japan, the term 'BE' is used as a synonym for CLE. When using the distal end of the palisade vessels as the EGJ, most of the Japanese patients in one study $(91.7 \%, 11$ of 12) showed BE $<5 \mathrm{~mm}$ in length [28], a finding which may cause a diagnostic issue.

Generally, the length of BE is a significant risk factor in the development of dysplasia and cancer, as we will describe below. Although EAC arising from SSBE (including ultra-short $\mathrm{BE}$ ) has been reported, to the best of our knowledge, no data confirming that ultra-short BE has any increased cancer risk has been found. In an era of growing endoscopic therapy for neoplastic BE, it is important to standardize the BE length. Unfortunately, proximal islands of columnar lining and ultra-short BE $(<1 \mathrm{~cm})$ are not included in the updated American College of Gastroenterology (ACG) guidelines (2008) for the diagnosis of BE [9].

\section{SIM (goblet cells) and carcinogenesis}

The divergence between the USA [9] and the British Society of Gastroenterology (BSG) guidance [26] relates to intestinalization and the presence of goblet cells on biopsy. The ACG defines BE as "a change in the distal esophageal epithelium of any length that can be recognized as 
columnar-type mucosa at endoscopy and is confirmed to have SIM by biopsy of the tubular esophagus" [9]. The basis for this definition relies mainly on the fact that most of the cases of EAC arise in BE mucosa with SIM, as shown by retrospective cohort studies [29-33]. It has been generally considered, therefore, that SIM in BE is a precancerous condition.

In contrast, the BSG does not require the confirmation of SIM in biopsies from the esophagus to establish the diagnosis of BE [26]. Although the endoscopic requirements are similar to the ACG guidelines, any histological type of columnar epithelium is regarded as acceptable to diagnose BE. The absence of SIM might actually be missed by poor endoscopic sampling due to inadequate numbers of biopsy specimens, thus supporting the BSG viewpoint that the demonstration of CLE in an appropriate endoscopic setting is sufficient for the diagnosis of BE. Crucial questions remain such as 'Is SIM the premalignant phenotype?' and 'Is it therefore the most significant feature for the diagnosis of BE?' [34]

The updated practice guidelines published in 2011 by the American Gastrointestinal Association (AGA) state that intestinal-type epithelium (SIM) is the only type of esophageal columnar epithelium that clearly predisposes a patient to malignancy [35]. In a subgroup analysis by status in BE, the incidence of EAC in patients with SIM in BE at an index biopsy was $0.23 \%$ patient-years (pyrs) $(95 \%$ confidence interval [CI] $0.18-0.29 \%$ per year), and the risk of cancer was significantly higher in patients with SIM than in patients whose first biopsies did not show SIM (0.04\% per year, $95 \%$ CI 0.02-0.08\% per year) [43].

However, it has been reported that cardia-type epithelium may not be normal, and a pair of studies revealed molecular abnormalities in such epithelium that are similar to those found in SIM [36, 37]. Liu et al. [36] reported that patients with esophageal columnar metaplasia, but without SIM (goblet cells), showed DNA content abnormalities statistically similar to metaplastic columnar epithelium with SIM. In an interesting clinical study by Takubo et al. [38], it was revealed that $71 \%$ of BE patients had cardiatype epithelium, not SIM, found adjacent to tiny EAC, and $57 \%$ had no SIM as detected in the specimen by endoscopic resection. Other studies indicated a similar finding, i.e., that non-SIM BE mucosa has the same cancer risk as that of intestinal-type mucosa [39-41].

Vieth et al. [42] searched for SIM associated with EAC and found that the incidence of SIM in the surrounding mucosa of EAC ranges from 30-100 \%. The risk of dysplasia or EAC is not necessarily related to the presence or absence of SIM, because the detection of SIM is strongly associated with the number of biopsy specimens obtained $[40,43]$. Taking into account these results, future classifications of BE might not require the presence of SIM, a policy which would increase the number of patients considered to be at risk.

Is the presence of SIM associated with a risk of developing EAC? The great majority of studies on the risk of cancer in BE have included patients with SIM either primarily or exclusively [44]. Although recent data suggest that cardia-type epithelium may well predispose to malignancy, the magnitude of that risk remains clear [35, 45], and thus the AGA does not recommend use of the term "BE" for patients with cardia-type epithelium [35].

\section{Risk factors for EAC or dysplasia}

\section{Incidence of EAC or dysplasia in BE patients}

$\mathrm{BE}$ is well recognized as a premalignant condition, and the incidence of EAC arising in individuals with $\mathrm{BE}$ is increasing in the West [46-48]. Surveillance endoscopy has thus been recommended for BE patients with the aim of detecting dysplasia and early cancer and subsequently improving survival [9]. Recommended surveillance intervals provided in the AGA medical position statement suggest intervals of 3-5 years for patients who have no dysplasia, 6-12 months for those with low-grade dysplasia (LGD), and every 3 months for patients with high-grade dysplasia (HGD) who receive no ablation therapy; however, it is a weak recommendation accompanied by lowquality evidence [35]. In Asia including Japan, although the incidence of gastroesophageal reflux disease (GERD) has been increasing in recent years [49-53], EAC remains rare and has not increased [54-57].

The true annual incidence of EAC in BE patients is unclear because cohort studies have shown considerable variation, ranging from $0.2-3.5 \%$ per year $[58,59]$. As Sikkema et al. [60] pointed out, however, these rates could have been overestimated as a result of publication bias in published BE surveillance studies, with evidence of a selective publication of small studies with high cancer incidence rates [44]. The rates may also have been affected by the difference in study populations, i.e., general population versus hospital-based studies. To the best of our knowledge, there have been no randomized controlled trials (RCTs) comparing surveillance with no surveillance in BE patients. Since RCTs comparing surveillance with nonsurveillance in BE patients in terms of cancer-related deaths are not likely to be conducted, a meta-analysis of both the risk of cancer and cancer-related deaths in BE could provide another way to address the question of true annual incidence of EAC in BE patients [60].

If RCTs are needed to clarify the incidence of EAC in BE patients, the RCTs must overcome overwhelming barriers in terms of both practical difficulties and ethical 
challenges [61]. Several systematic reviews and metaanalyses on the EAC risk in BE patients $[60,62-66]$ are summarized in Table 1. Among these studies, the rate of progression in BE without dysplasia at baseline to EAC is low, ranging from $0.33 \%(95 \%$ CI $0.28-0.38 \%)$ to $0.598 \%(95 \%$ CI $0.505-0.691 \%)$ annually $[65,66]$. Bhat et al. [43] reported the risk of malignant progression in $\mathrm{BE}$ patients in Northern Ireland, in which they studied the incidence of not only EAC but also gastric cardia cancer or $\mathrm{BE}$ with dysplasia. According to their results, when calculating the incidence of only EAC, the incidence of EAC was $0.16 \%$ pyrs in the whole cohort, $0.10 \%$ pyrs in the nondysplastic BE patient group, and $0.92 \%$ pyrs in the LGD group. In contrast, the pooled annual incidence of EAC in the patients with dysplasia at baseline, LGD, or HGD ranged from 2.8/1,000-6.3/1,000 pyrs. However, there are some problems in these data such as (1) publication bias, (2) it was not reported whether the authors excluded patients with dysplasia such as LGD or HGD at baseline, and (3) it was not reported whether patients had documented SIM histologically.

Although there are several studies showing the presence of dysplasia as a risk factor for the development of EAC as mentioned above, a meta-regression analysis by Thomas et al. [63] showed that the presence of LGD on an index biopsy had no significant effect on the cancer incidence rates. This may be explained by the wide intra- and interobserver variability in the reporting of LGD, even among expert pathologists. The number of pathologists reporting histology was not clear from the studies. It is therefore possible that several patients with LGD on index biopsy may not have had dysplasia at all. In addition, difficulties in the histological diagnosis for HGD or EAC may occur when biopsy samples are evaluated, and thus patients with confirmed HGD at baseline should be excluded from the study.

Table 1 Incidence of esophageal adenocarcinoma and high-grade dysplasia among patients with Barrett's esophagus

\begin{tabular}{|c|c|c|c|c|c|c|}
\hline \multirow[t]{2}{*}{ References } & \multirow[t]{2}{*}{ Year } & \multicolumn{2}{|c|}{ Incidence rate/1,000 pyrs $(95 \% \mathrm{CI})$} & \multirow{2}{*}{$\begin{array}{l}\text { Definition of } \\
\text { BE }\end{array}$} & \multirow{2}{*}{$\begin{array}{l}\text { On initial } \\
\text { endoscopy }\end{array}$} & \multirow[t]{2}{*}{ Publication bias } \\
\hline & & EAC & EAC and HGD & & & \\
\hline $\begin{array}{l}\text { Chang } \\
\text { et al. } \\
{[62]}\end{array}$ & 2007 & $\begin{array}{l}\text { Controlled studies (RCT } \\
\text { and cohort study) } \\
4.8(1.7-11.1) \text { in surgically } \\
\text { treated group } \\
6.5(2.6-13.8) \text { in medically } \\
\text { treated group }\end{array}$ & Not specified & $\begin{array}{l}\text { Histologically } \\
\text { SIM }\end{array}$ & $\begin{array}{l}\text { Including LGD and } \\
\text { HGD }\end{array}$ & $\begin{array}{l}\text { Heterogeneity in } \\
\text { surgically } \\
\text { treated group }\end{array}$ \\
\hline $\begin{array}{l}\text { Thomas } \\
\text { et al. } \\
\text { [63] }\end{array}$ & 2007 & $\begin{array}{l}7(6-9) \text { [7 (4-12) in the UK, } \\
7(4-9) \text { in the US, } 8 \\
(5-12) \text { in Europe, and } 5 \\
(1-25) \text { in Australia and } \\
\text { New Zealand] }\end{array}$ & $\begin{array}{l}9(7-11)[9(5-16) \text { in the UK, } \\
8(6-11) \text { in USA, } 11(7-17) \\
\text { in Europe, and } 5(1-25) \text { in } \\
\text { Australia and New } \\
\text { Zealand] }\end{array}$ & $\begin{array}{l}\text { Endoscopically } \\
\text { or } \\
\text { histologically } \\
\text { SIM }\end{array}$ & Including LGD & $\begin{array}{l}\text { No publication } \\
\text { bias in the UK } \\
\text { and EU studies } \\
\text { but in the USA } \\
\text { studies }\end{array}$ \\
\hline $\begin{array}{l}\text { Yousef } \\
\text { et al. } \\
{[64]}\end{array}$ & 2008 & $\begin{array}{l}4.1(3.1-5.5)[7.0(4.2-11.5) \\
\text { in the UK, } 6.4(4.1-9.8) \text { in } \\
\text { the US, and } 5.6(3.7-8.5) \\
\text { in other Europe] }\end{array}$ & $\begin{array}{l}9.1(5.9-13.8) \text { (with } \\
\text { heterogeneity) }\end{array}$ & $\begin{array}{l}\text { Endoscopically } \\
\text { or } \\
\text { histologically } \\
\text { SIM, mainly } \\
\text { histologically }\end{array}$ & $\begin{array}{l}\text { Including LGD but } \\
\text { excluded HGD at } \\
\text { baseline, and early } \\
\text { incident cancer } \\
\text { and HGD }\end{array}$ & Not significant \\
\hline $\begin{array}{l}\text { Wani et al. } \\
\text { [65] }\end{array}$ & 2009 & $\begin{array}{l}5.98(5.05-6.91) \text { in } \\
\text { nondysplastic BE } \\
16.98(13.1-20.85) \text { in LGD } \\
65.8 \%(49.7-81.9) \text { in HGD } \\
\text { (with heterogeneity) }\end{array}$ & Not specified & $\begin{array}{l}\text { Histologically } \\
\text { SIM }\end{array}$ & $\begin{array}{l}\text { Separately } \\
\text { evaluated in } \\
\text { nondysplastic BE, } \\
\text { LGD, and HGD }\end{array}$ & $\begin{array}{l}\text { The incidence of } \\
\text { EAC in only } \\
\text { patients with } \\
\text { LGD }\end{array}$ \\
\hline $\begin{array}{l}\text { Sikkema } \\
\text { et al. } \\
{[60]}\end{array}$ & 2010 & $\begin{array}{l}6.3(4.7-8.4) \text { (with } \\
\text { heterogeneity) } \\
\text { [6.3 (4.2-9.3) in the UK, } 6.5 \\
(3.4-12.4) \text { in the USA, 5.6 } \\
(3.5-9.2) \text { in other Europe, } \\
\text { and } 6.5(3.5-12.2) \text { in } \\
\text { Australia] }\end{array}$ & $\begin{array}{l}10.2(7.5-14.0) \text { (with } \\
\text { heterogeneity) } \\
{[13.0(7.4-22.8) \text { in the UK, }} \\
11.0(6.9-17.5) \text { in the USA, } \\
7.3(3.6-15.0) \text { in other } \\
\text { Europe, and } 6.5(3.5-12.2) \\
\text { in Australia] }\end{array}$ & $\begin{array}{l}\text { Histologically } \\
\text { SIM or } \\
\text { columnar } \\
\text { lined } \\
\text { esophagus }\end{array}$ & $\begin{array}{l}\text { Including LGD and } \\
\text { HGD }\end{array}$ & $\begin{array}{l}\text { Present among } \\
\text { studies from the } \\
\text { USA, but not } \\
\text { from the UK and } \\
\text { other studies }\end{array}$ \\
\hline $\begin{array}{l}\text { Desai } \\
\text { et al. } \\
\text { [66] }\end{array}$ & 2012 & $3.3(2.8-3.8)$ & Not specified & $\begin{array}{l}\text { Histologically } \\
\text { SIM }\end{array}$ & Nondysplastic BE & Not significant \\
\hline
\end{tabular}

$E A C$ esophageal adenocarcinoma, $H G D$ high-grade dysplasia, $L G D$ low-grade dysplasia, $B E$ Barrett's esophagus, $R C T$ randomized controlled trial, SIM specialized intestinal metaplasia, $C I$ confidence intervals, pyrs patient-years 
It may also be possible that the presence or absence of SIM at baseline influences the incidence of EAC during follow-up. Although it is believed that the presence of SIM in $\mathrm{BE}$ raises the cancer risk, it is now clear that EAC can occur without SIM being detected. In an analysis by Bhat et al. [43], the incidence of EAC in patients with SIM in $\mathrm{BE}$ at index biopsy was $0.23 \%$ pyrs $(95 \% \mathrm{CI} 0.18-0.29 \%$ per year), and the risk of cancer was significantly higher in patients with SIM compared to patients whose first biopsies did not show SIM (0.04 \% per year, $95 \%$ CI 0.02-0.08\% per year).

More recently, a large nationwide population-based cohort study in the Netherlands involving BE patients with histologically confirmed SIM revealed that the annual risk of EAC was $0.4 \%$, and after excluding HGD/EAC cases detected within 1 year after $\mathrm{BE}$ diagnosis, the incidence rates were 4.3/1,000 pyrs (95\% CI 3.4-5.5) for EAC and 5.8/1,000 pyrs (95 \% CI 4.6-7.0) for HGD/EAC combined [67]. LGD at diagnosis was found to be an independent predictor of malignant progression in that study. A similar population-based cohort study in Denmark reported that the incidence of EAC and HGD among patients with BE, with or without LGD was $0.12 \%$ pyrs (95\% CI 0.9-1.5) and $0.19 \%$ pyrs (95\% CI 1.6-2.3), respectively; these values were lower than previously reported data. The relative risks of EAC and HGD, i.e., 11.3 (95 \% CI 8.8-14.4) and 65.3 (95\% CI 53.5-79.0), were as high among patients with $\mathrm{BE}$ as in the general population, but significantly lower than those found in earlier studies [68]. These results may call into question the cost-effectiveness of generalized $\mathrm{BE}$ surveillance programs in the West. There have been few prospective cohort studies on the incidence of EAC or dysplasia in Asia and Japan.

\section{Geographic difference of cancer risk}

A geographic difference in EAC incidence in BE between the UK and the USA was reported, with the incidence in the UK being twice that of the USA [69]. However, in the meta-analysis by Thomas et al. [63], the incidence in the UK $(0.7 \%$ per year) was the same as the incidence in the
USA ( $0.7 \%$ per year), providing no support for the hypothesis of geographic variation in cancer incidence. However, Thomas et al. mentioned that this result may be confounded by the inclusion of two large UK studies. The exclusion of these studies for the reasons stated above would support published figures showing a higher cancer incidence in the UK compared to the USA. A geographic variation in $\mathrm{BE}$ cancer risk has been suggested by another group [46]. Very small differences in the EAC incidence were reported between different geographic regions, with only a slightly higher EAC incidence in the USA and UK compared to other European countries, which is in line with other studies [63, 64]. The incidence in Australia and New Zealand was slightly lower than that in the USA and Europe including the UK [63].

\section{BE length and carcinogenesis}

It has been thought that patients with long-segment $\mathrm{BE}$ (LSBE $\geq 3 \mathrm{~cm}$ BE length) have a much higher risk of developing EAC than individuals in the general population [8, 70-72]. Avidan et al. [73] reported that each centimetre of elongation of BE carried with it a $17 \%$ increase in the risk of developing HGD or EAC. A follow-up study by Weston et al. [74] showed that the incidence of EAC was significantly lower in patients with SSBE ( $<3 \mathrm{~cm}$ in length) than in those with LSBE (0 vs $7.5 \%$ ). Avidan et al. also reported the incidence of the development of multifocal HGD/EAC as $23.1 \%$ for patients with $>6 \mathrm{~cm}$ of $\mathrm{BE}$ and $3.6 \%$ for $\mathrm{BE}$ lengths of $>2$ and $\leq 6 \mathrm{~cm}$. According to a review by Caygill et al. [61], the risk of overall or incident cancers was greater for SSBE than for LSBE $(3-6 \mathrm{~cm})$ but the greatest risk is for segments $>6 \mathrm{~cm}$. Taken together, these results indicate that dysplasia and EAC can occur in BE of all lengths.

Among three meta-analyses (Table 2), two demonstrated that the risk for EAC was lower in patients with SSBE than in those with LSBE [63, 66], but the other did not show the trend [64]. There have been several reports on the incidence of EAC in patients with SSBE [75-79], but relatively few patients with SSBE were included in these meta-analyses; overall, they accounted for $<10 \%$ of the total number of pyrs

Table 2 Association between the length of Barrett's esophagus and cancer risk

\begin{tabular}{|c|c|c|c|c|}
\hline \multirow[t]{2}{*}{ References } & \multirow[t]{2}{*}{ Year } & \multicolumn{2}{|l|}{ Incidence of EAC (95\% CI) } & \multirow[t]{2}{*}{ Publication bias } \\
\hline & & SSBE & LSBE & \\
\hline Thomas et al. [63] & 2007 & $\begin{array}{l}\text { OR } 0.55(0.19-1.5) \\
\text { (EAC risk in patients } \\
\text { with SSBE compared to LSBE) }\end{array}$ & & $\begin{array}{l}\text { NS (except } \\
\text { the USA studies) }\end{array}$ \\
\hline Yousef et al. [64] & 2008 & $6.1 / 1,000$ pyrs $(3.1-12.2)$ & $6.7 / 1,000$ pyrs $(5.2-8.6)$ & NS \\
\hline Desai et al. [66] & 2012 & $1.9 / 1,000$ pyrs $(0.8-3.4)$ & & NS \\
\hline
\end{tabular}

$E A C$ esophageal adenocarcinoma, SSBE short-segment Barrett's esophagus, $L S B E$ long-segment Barrett's esophagus, $N S$ not significant, $C I$ confidence intervals, $O R$ odds ratio, pyrs patient-years 
of follow-up. Desai et al. [66] revealed that the risk of EAC among patients with SSBE is notably lower than the pooled estimate for all patients with BE. The sub-analysis by Thomas et al. [63] showed significantly greater lengths of BE in patients who developed cancer compared to those who did not, while there was a non-significant trend toward reduction in the risk of developing EAC in the patients with SSBE compared to conventional $\mathrm{BE}$ (odds ratio [OR] 0.55, $95 \% \mathrm{CI}$ 0.19-1.5), although this analysis was based on data from a small number of studies. These data appear to support the previous contention that patients with longer BE are at higher risk of developing EAC [80].

Horwhat et al. [18] also showed that the incidence density for EAC/dysplasia in an LSBE cohort was $7.7 \%$ pyrs, whereas the incidence density of dysplasia was $1.8 \%$ pyrs in the SSBE cohort. In contrast, another meta-analysis by Yousef et al. [64] found no difference in the pooled estimate of overall cancer incidence between patients with LSBE (0.67\% pyrs) and those with SSBE (0.61\% pyrs). Rudolph et al. [81] reported that the risk for EAC in patients with SSBE was not substantially lower than that in patients with LSBE, and when patients with HGD at baseline were excluded, a nonsignificant trend was observed. However, their study was not among those analyzed in the two meta-analyses [63, 66] described above. The presence or absence of dysplasia at baseline is likely to affect the results, and all patients with any degree of dysplasia at baseline should be excluded from analysis. Taken together, these results indicate that dysplasia and EAC can occur in patients with BE of any length, whereas the risk may be associated with BE length.

A large cohort multicenter study from the USA indicated that compared to non-progressors, patients who developed HGD or EAC had longer BE (6.1 vs $3.5 \mathrm{~cm}$; $p<0.001$ ), and a logistic regression analysis showed a $28 \%$ increase in the risk of HGD or EAC for every $1 \mathrm{~cm}$ increase in $\mathrm{BE}$ length $(p=0.01)$ [82]. That study also revealed that the annual incidence of HGD or EAC was $0.67 \% / y e a r$ during the mean follow-up period (5.5 years).

\section{H. pylori infection and carcinogenesis}

There are many studies on the relationship between H. pylori and GERD. Although the association is complex, it has generally been considered that $H$. pylori infection, with the cytotoxin-associated gene A ( $\operatorname{cag} A)$-positive strain, is inversely associated with the risk of GERD, and thus $H$. pylori may have a protective role against GERD. In contrast, several meta-analyses have indicated that H. pylori eradication does not seem to aggravate GERD or increase the rate of new development of GERD.

The association between $H$. pylori infection and $\mathrm{BE}$ or BE-associated EAC is controversial. A meta-analysis by
Rokkas et al. [83] showed a significant inverse relationship between $H$. pylori infection and both EAC (pooled OR $0.52,95 \%$ CI $0.37-0.73, p<0.001$ ) and BE (pooled OR $0.64,95 \%$ CI $0.43-0.94, p<0.025)$, which might suggest a protective role of the infection in these entities. However, their meta-analysis included patients with GERD, functional dyspepsia and a variety of non-BE diseases as controls, which would not accurately reflect the true effect size of $H$. pylori infection in BE versus healthy controls.

There are various reports on the association between $H$. pylori and BE. According to a meta-analysis by Fischbach et al. [85], H. pylori, especially the cagA-positive strain of H. pylori, tended to be protective for BE in most studies; however, there was obvious heterogeneity across the studies. The effect of $H$. pylori on BE varied by geographic location and in the presence of selection and information biases. When four studies with obvious selection and information bias were excluded, a protective effect of $H$. pylori on $\mathrm{BE}$ was found (relative risk 0.46, $95 \% \mathrm{CI}$ 0.35-0.60). Wang et al. [86] reported that there was no significant difference in the overall prevalence of $H$. pylori infection between $\mathrm{BE}$ patients and controls (42.9 vs $43.9 \%$, OR $0.74,95 \%$ CI $0.40-1.37, p=0.34$ ), but with significant heterogeneity. A subgroup analysis showed that the prevalence of $H$. pylori infection was significantly lower in the BE group compared to the endoscopically normal healthy controls ( 23.1 vs $42.7 \%$, OR $0.50,95 \% \mathrm{CI}$ $0.27-0.93, \quad p=0.03)$ with significant heterogeneity observed between studies.

In contrast, $H$. pylori infection was significantly increased in BE patients in a few studies using healthy blood donors without endoscopic examination as 'normal controls' (71.2 vs 48.1 \%, OR 2.21, $95 \%$ CI 1.07-4.55) in a meta-analysis. Thrift et al. [87] reported a populationbased case-control study which found that $H$. pylori infection was inversely associated with BE, whereas there was some variation in the magnitude of risk estimates across strata of age, gender, reflux symptoms, and use of proton pump inhibitors (PPIs) or $\mathrm{H}_{2}$-receptor antagonists $\left(\mathrm{H}_{2} \mathrm{RAs}\right.$ Further studies are needed to test this association, and the studies should enroll patients prospectively to ensure standard BE diagnostic methods, $H$. pylori detection methods, and overall high study quality.

In contrast, in a rat model of chronic gastroesophageal reflux, when $H$. pylori colonized in the esophagus, the bacteria increased the severity of esophageal inflammation and the incidence of BE and EAC [84].

It may be true that there is marked geographic heterogeneity in the association between $H$. pylori and BE [86, 88, 89]. As found in other studies, a study from Japan showed that $H$. pylori infection may play a protective role in the development of BE (especially LSBE), although the number of patients evaluated was limited [90]. The same 
group proposed that the preservation of gastric acid secretion might be important for the development of adenocarcinoma at the EGJ (including EAC) in Japanese people, irrespective of the $H$. pylori infection status [91]. Namely, there may be two distinct types of cancer at the EGJ-EAC (BE cancer) associated with high gastric acid secretion and reflux of gastric acid into the esophagus and EGJ adenocarcinoma (non-BE cancer) resembling distal gastric cancer associated with gastric atrophy and low gastric acid secretion $[92,93]$.

Nakajima and Hattori conducted a systematic review and reported that even for patients with accompanying BE, the expected incidence of either gastric cancer or EAC with persistent infection was higher than that of EAC after $H$. pylori eradication, and they hypothesized that if the treatment of $H$. pylori infection lowers the incidence of gastric cancer, it should be recommended for patients with corpus atrophy at all ages irrespective of the presence of $\mathrm{BE}$, especially in populations with a high prevalence of gastric cancer [94].

\section{Obesity and carcinogenesis}

It is well known that simple obesity as measured by body mass index (BMI) may be an independent risk factor for GERD, reflux esophagitis (RE), BE, and EAC [95, 96]. In contrast, waist circumference (WC) rather than BMI is associated with esophageal acid exposure, with larger WCs leading to a risk of GERD and BE [97]. Recent epidemiological studies showed that WC and the waist-to-hip ratio (WHR), both of which are associated with increased abdominal fat, are risk factors for BE independent of the $\mathrm{BMI}$, with the association between BMI and BE no longer observed after adjustment for WC or WHR [98, 99].

El-Serag et al. [100] estimated that each $10 \mathrm{~cm}^{2}$ increase in visceral adipose tissue (VAT), which was calculated from CT scan images, was associated with a $9 \%$ increase in the risk of BE, and VAT remained independently associated with BE in the model adjusted for BMI. However, there has been little study of the correlation between obesity and BE in Japan. Akiyama et al. [101] reported a retrospective study on the positive association between VAT and BE in Japanese patients with non-alcoholic fatty liver disease, but the strength of the risk of BE was very weak (OR 1.0074, $95 \%$ CI 1.0001-1.0147, $p=0.0472$ ).

It thus remains controversial whether obesity is actually an independent risk factor for BE in a Japanese population. Because the prevalence of abdominal obesity varies by gender and ethnicity [102], it is possible that body fat distribution may predict the risk of not only BE but also EAC better than total obesity. It is well known that the prevalence of GERD and its complications, such as RE and BE, may vary substantially by gender and ethnicity [103-
105]. Many studies have shown that obesity was associated with an increased risk for EAC [106-117]. All of these studies showed a positive association between being overweight $\left(\right.$ BMI $>25 \mathrm{~kg} / \mathrm{m}^{2}$ ) or obese (BMI $>30 \mathrm{~kg} / \mathrm{m}^{2}$ ) and the development of EAC (Table 3). These studies indicated that obesity was associated with an approximate 1.5- to 2.5-fold increase in the risk of EAC compared to normal BMI values.

The FINBAR (Factors Influencing the Barrett's Adenocarcinoma Relationship) study [116] comparing risk factors for both BE and EAC showed that patients with a high BMI were significantly more likely to develop EAC but not BE (with SIM and $\geq 3 \mathrm{~cm}$ in length), thus demonstrating important differences between $\mathrm{BE}$ and EAC in their association with BMI. This result indicates that the pathogenesis of EAC may be different from that of GERD including BE [113]. In the FINBAR study, no relationship was observed between WHR and EAC (OR 0.80, $95 \%$ CI $0.50-1.28$ ) or between WHR and BE (OR 1.09, $95 \%$ CI 0.68-1.73), but the reasons for these results were not clear [116]. The results of observational studies may be influenced by unmeasured confounders. Some factors, such as physical activity and dietary composition, may be related to BMI and were not routinely adjusted for in all studies; however, studies that included estimates with and without adjustment for these variables did not show a substantial influence of these factors on the risk estimates [109].

When a tumor is located at the EGJ, especially at the advanced stage, the diagnosis of the cancer may be difficult; possible diagnoses include EAC alone, gastric cardiac cancer alone, or the combination of EAC with cardiac cancer [118]. Two meta-analyses examined the association between obesity and cancer divided into two types, EAC and cardiac cancer of the stomach $[96,118]$. Both metaanalyses revealed a positive association between high BMI and the risk for EAC, and possibly the risk for cardiac cancer because of the heterogeneous results.

\section{Neoplastic prevention}

PPIs and chemoprevention in BE

For GERD and BE patients without dysplasia, it is debated which therapy, medical or surgical, is appropriate for the prevention of EAC. One advantage of anti-reflux surgery is the creation of a mechanical valve which prevents all forms of gastroesophageal reflux. On the other hand, PPIs and $\mathrm{H}_{2}$ RAs reduce the acidity of gastric secretions but do not prevent nonacidic reflux [119], which has been implicated in carcinogenesis [120]. These observations have fueled speculation that surgical anti-reflux procedures may prevent the development of EAC more effectively than 
Table 3 Association between esophageal adenocarcinoma and body mass index

\begin{tabular}{|c|c|c|c|c|c|c|c|}
\hline References & Year & Country & Design & BMI categories & $\begin{array}{l}\text { Adjusted odds ratio } \\
(95 \% \mathrm{CI})\end{array}$ & $\begin{array}{l}\text { BMI } \\
\text { reference }\end{array}$ & Adjustments \\
\hline \multirow[t]{2}{*}{$\begin{array}{l}\text { Brown et al. } \\
\text { [106] }\end{array}$} & \multirow[t]{2}{*}{1995} & \multirow[t]{2}{*}{ USA } & \multirow[t]{2}{*}{ Case-control study } & $25.1-26.6$ & $\begin{array}{l}1.2(0.6-2.3) \text { in } \\
\text { white men }\end{array}$ & \multirow[t]{3}{*}{$<23.1$} & \multirow[t]{2}{*}{$\begin{array}{l}\text { Age, area, smoking, } \\
\text { liquor use, and income }\end{array}$} \\
\hline & & & & $>26.6$ & $\begin{array}{l}3.1(1.8-5.3) \text { in } \\
\text { white men }\end{array}$ & & \\
\hline $\begin{array}{l}\text { Vaughan et al. } \\
\text { [107] }\end{array}$ & 1995 & USA & $\begin{array}{l}\text { Population-based } \\
\text { case-control study }\end{array}$ & $\begin{array}{l}\text { Percentile } \\
\quad 90-100 \%\end{array}$ & $2.5(1.2-5.0)$ & & $\begin{array}{l}\text { Age, gender, education, } \\
\text { race, cigarette use, and } \\
\text { alcohol consumption }\end{array}$ \\
\hline \multirow[t]{4}{*}{$\begin{array}{l}\text { Chow et al. } \\
\text { [108] }\end{array}$} & \multirow[t]{4}{*}{1998} & \multirow[t]{4}{*}{ USA } & \multirow[t]{4}{*}{$\begin{array}{l}\text { Population-based } \\
\text { case-control study }\end{array}$} & $\begin{array}{l}\text { Males } \\
\quad 25.09-27.31\end{array}$ & \multirow[t]{2}{*}{$2.0(1.3-3.3)$} & $\begin{array}{l}\text { Males } \\
\quad<23.12\end{array}$ & \multirow{4}{*}{$\begin{array}{l}\text { Geographic location, } \\
\text { age, sex, race, } \\
\text { cigarette smoking, and } \\
\text { respondent status }\end{array}$} \\
\hline & & & & $\begin{array}{l}\text { Females } \\
\quad 24.13-27.43\end{array}$ & & \multirow[t]{3}{*}{$\begin{array}{l}\text { Females } \\
\quad<21.95\end{array}$} & \\
\hline & & & & Males $\geq 27.32$ & $2.9(1.8-4.7)$ & & \\
\hline & & & & Females $\geq 27.44$ & & & \\
\hline \multirow[t]{6}{*}{$\begin{array}{l}\text { Lagergren } \\
\text { et al. [109] }\end{array}$} & \multirow[t]{6}{*}{2001} & \multirow[t]{6}{*}{ Sweden } & \multirow[t]{6}{*}{$\begin{array}{l}\text { Population-based } \\
\text { case-control study }\end{array}$} & Males 22.3-23.9 & $2.2(1.0-4.7)$ & $\begin{array}{l}\text { Males } \\
\quad<22.3\end{array}$ & \multirow{6}{*}{$\begin{array}{l}\text { Age, sex, race, tobacco } \\
\text { smoking, alcohol use, } \\
\text { socioeconomic status, } \\
\text { reflux symptoms, } \\
\text { intake of fruit and } \\
\text { vegetables, energy } \\
\text { intake, and physical } \\
\text { activity }\end{array}$} \\
\hline & & & & Females 21.1-22.4 & & \multirow[t]{5}{*}{$\begin{array}{l}\text { Females } \\
\quad<21.1\end{array}$} & \\
\hline & & & & Males 24.0-25.5 & $3.8(1.9-7.7)$ & & \\
\hline & & & & Females 22.5-24.2 & & & \\
\hline & & & & Males $>25.6$ & $7.6(3.8-15.2)$ & & \\
\hline & & & & Females $>24.2$ & & & \\
\hline \multirow[t]{4}{*}{ Wu et al. [110] } & \multirow[t]{4}{*}{2001} & \multirow[t]{4}{*}{ USA } & \multirow{4}{*}{$\begin{array}{l}\text { Population-based } \\
\text { case-control study }\end{array}$} & Males $>25$ to $\leq 28$ & $1.34(0.9-2.1)$ & \multirow{4}{*}{$\begin{array}{l}\text { Males } \\
\quad \leq 23 \\
\text { Females } \\
\leq 22\end{array}$} & \multirow{4}{*}{$\begin{array}{l}\text { Smoking status, age, } \\
\text { sex, race, birthplace, } \\
\text { and education }\end{array}$} \\
\hline & & & & $\begin{array}{l}\text { Females }>25 \text { to } \\
\quad \leq 28.25\end{array}$ & & & \\
\hline & & & & Males $>28$ & $1.91(1.3-2.9)$ & & \\
\hline & & & & Females $>28.25$ & & & \\
\hline \multirow[t]{4}{*}{$\begin{array}{l}\text { Engeland et al. } \\
\text { [112] }\end{array}$} & \multirow[t]{4}{*}{2004} & \multirow[t]{6}{*}{ Norway } & \multirow[t]{4}{*}{$\begin{array}{l}\text { Retrospective cohort } \\
\text { study }\end{array}$} & $25.0-29.9$ in men & $\begin{array}{l}\text { RR } 1.80 \\
\quad(1.48-2.19)\end{array}$ & \multirow[t]{6}{*}{$18.5-24.9$} & Age and year of birth \\
\hline & & & & $\begin{array}{l}25.0-29.9 \text { in } \\
\text { women }\end{array}$ & $\begin{array}{l}\text { RR } 1.64 \\
\quad(1.08-2.49)\end{array}$ & & \\
\hline & & & & $\geq 30.0$ in men & $\begin{array}{l}\text { RR } 2.58 \\
\quad(1.81-3.68)\end{array}$ & & \\
\hline & & & & $\geq 30.0$ in women & $\begin{array}{l}\text { RR } 2.06 \\
\quad(1.25-3.39)\end{array}$ & & \\
\hline Hampel et al. & 2005 & & Meta-analysis & $\geq 25$ & $1.52(1.147-2.009)$ & & \\
\hline & & & & $>30$ & $2.78(1.850-4.164)$ & & \\
\hline Lindblad et al. & 2005 & UK & Population-based & $25-29$ in men & $1.87(1.25-2.80)$ & $20-24$ & Adjusted for age, \\
\hline [113] & & & case-control study & $25-29$ in women & $1.08(0.50-2.33)$ & & \\
\hline & & & & $\geq 30$ in men & $1.76(1.03-3.02)$ & & consumption and \\
\hline & & & & $\geq 30$ in women & $2.13(0.97-4.71)$ & & reflux \\
\hline $\begin{array}{l}\text { Samanic et al. } \\
{[114]}\end{array}$ & 2006 & $\begin{array}{l}\text { Sweden } \\
(\text { men })\end{array}$ & Prospective cohort study & $25.0-29.9$ & $\begin{array}{l}\text { RR } 1.58 \\
\quad(0.98-2.53)\end{array}$ & $18.5-24.9$ & $\begin{array}{l}\text { Attained age (10-year } \\
\text { intervals) and calendar } \\
\text { year (5-year intervals), } \\
\text { and smoking status, } \\
\text { and relative to normal } \\
\text { weight subjects }\end{array}$ \\
\hline & & & & $>30.0$ & $\begin{array}{l}\text { RR } 2.72 \\
\quad(1.33-5.55)\end{array}$ & & \\
\hline
\end{tabular}


Table 3 continued

\begin{tabular}{|c|c|c|c|c|c|c|c|}
\hline References & Year & Country & Design & BMI categories & $\begin{array}{l}\text { Adjusted odds ratio } \\
(95 \% \mathrm{CI})\end{array}$ & $\begin{array}{l}\text { BMI } \\
\text { reference }\end{array}$ & Adjustments \\
\hline $\begin{array}{l}\text { Kubo and } \\
\text { Corley [118] }\end{array}$ & 2006 & & Meta-analysis & $\begin{array}{l}25-28 \text { in men } \\
25-28 \text { in women } \\
\geq 28 \text { in men } \\
\geq 28 \text { in women }\end{array}$ & $\begin{array}{l}1.8(1.5-2.2) \\
1.5(1.1-2.2) \\
2.4(1.9-3.2) \\
2.1(1.4-3.2)\end{array}$ & $\begin{array}{l}\geq 18.5 \text { to } \\
<25\end{array}$ & \\
\hline $\begin{array}{l}\text { Anderson } \\
\text { et al. [116] }\end{array}$ & 2007 & Ireland & $\begin{array}{l}\text { Population-based } \\
\text { case-control study }\end{array}$ & $\begin{array}{l}25.0-28.1 \text { ( } 5 \text { years } \\
\text { in tertiles) } \\
>28.1 \text { ( } 5 \text { years in } \\
\text { tertiles) }\end{array}$ & $\begin{array}{l}1.74(0.66-1.97) \\
2.69(1.62-4.467)\end{array}$ & & $\begin{array}{l}\text { Sex, age at interview } \\
\text { date, smoking status, } \\
\text { alcohol intake }(\mathrm{g}), \\
\text { year of full-time } \\
\text { education and job type }\end{array}$ \\
\hline $\begin{array}{l}\text { Abnet et al. } \\
{[115]}\end{array}$ & 2008 & USA & Prospective cohort study & $\begin{array}{l}\geq 25 \text { to }<30 \\
\geq 30 \text { to }<35 \\
\geq 35\end{array}$ & $\begin{array}{l}\text { HR } 1.65 \\
\quad(1.26-2.18) \\
\text { HR } 1.91 \\
\quad(1.38-2.66) \\
\text { HR } 2.27 \\
\quad(1.44-3.59)\end{array}$ & $\begin{array}{l}\geq 18.5 \text { to } \\
<25\end{array}$ & $\begin{array}{l}\text { Age, sex, cigarette } \\
\text { smoking, alcohol } \\
\text { consumption, } \\
\text { education, fruit and } \\
\text { vegetable } \\
\text { consumption and } \\
\text { physical activity }\end{array}$ \\
\hline
\end{tabular}

$B M I$ body mass index, $C I$ confidence intervals, $R R$ relative risk, $H R$ hazard ratio

medical anti-secretory therapy. A systematic review by Chang et al. [62] showed that the incidence rate of EAC was 2.8/1,000 pyrs in surgically treated patients and 6.3/ 1,000 pyrs in medically treated patients $(p=0.034)$. When controlled studies were evaluated, however, the incidence rates were 4.8/1,000 and 6.5/1,000 pyrs in surgical and medical patients, respectively $(p=0.320)$. The likely reason for the discrepancy is the heterogeneity in incidence rates in surgically treated patients between the controlled studies and the case series $(p=0.014)$. These results thus indicate that anti-reflux surgery in patients with BE does not prevent the development of EAC appreciably more than medical therapy.

There is some evidence to suggest that PPIs can lead to a partial regression of $\mathrm{BE}[121,122]$ and delay the progression to dysplasia or EAC [123, 124]. Accordingly, the increasing use of PPIs since the late 1980s might have contributed to the slight drop in the incidence of EAC over the past several decades. Moreover, since the 1990s, several studies using varying doses of PPIs reported partial regression or the development of squamous islands [121, 125-128], while circumferential regression of the columnarized segment was rare.

Epidemiological studies have shown that the long-term use of PPIs is associated with lower rates of dysplasia and EAC in patients with BE [122, 124, 129-131], except for one study [132]. In two other studies, the early use of a PPIs after the diagnosis of BE was associated with a decreased risk of developing dysplasia or EAC [122, 129] (Table 4). The available data are insufficient to draw any definite conclusions [133, 134]. As the AGA noted [45], the evidence to support potent acid suppression with PPIs as a chemopreventive strategy in BE is largely indirect. A number of observational studies have found an inverse correlation between the long-term use of PPIs and the incidence of dysplasia and EAC in patients with BE [122124, 135]. Some prospective clinical studies have shown that PPI therapy is associated with a decrease in proliferation markers, a potentially cancer-protective effect, in biopsy specimens of Barrett's metaplasia [136-138]. However, prospective clinical studies have yet to prove that PPI therapy can prevent the development of dysplasia and its progression in $\mathrm{BE}$, and thus the quality of evidence of the association is low [35]. Indeed, García Rodríguez et al. [130] reported that individuals with long-term use of PPIs or $\mathrm{H}_{2} \mathrm{RAs}$ for 'esophageal' indication, i.e., reflux symptoms, esophagitis, BE, or hiatal hernia, showed a five-fold increased risk of EAC (OR 5.42, 95 \% CI 3.13-9.39).

Taken together, these studies suggest that the use of PPIs may prevent the development of dysplasia or EAC in BE patients, although it could not completely eliminate the risk of neoplastic progression. A large-scale, long-term, multicenter randomized controlled trial is needed to explore the usefulness of PPIs as a chemopreventive agent for dysplasia or EAC.

Aspirin/nonsteroidal anti-inflammatory drugs and chemoprevention

A meta-analysis showed that the use of aspirin or nonsteroidal anti-inflammatory drugs (NSAIDs) was protective against EAC (OR 0.67, $95 \%$ CI 0.51-0.87) [139]. Two prospective studies also showed that NSAID use reduced the risk of neoplastic progression in patients with BE [140, 141]. A study from Australia showed that patients who took aspirin at least weekly had significantly lower risks of 
Table 4 Use of proton pump inhibitors and risk of esophageal adenocarcinoma or high-grade dysplasia

\begin{tabular}{|c|c|c|c|c|c|c|}
\hline References & Year & Design & $\begin{array}{l}\text { Histology } \\
\text { subtypes of } \\
\text { outcome }\end{array}$ & Medication use & $\begin{array}{l}\text { Adjusted odds } \\
\text { ratio }(95 \% \mathrm{CI})\end{array}$ & Adjustments \\
\hline $\begin{array}{l}\text { El-Serag } \\
\text { et al. [122] }\end{array}$ & 2004 & $\begin{array}{l}\text { Prospective } \\
\text { study }\end{array}$ & Dysplasia & After BE diagnosis & $\begin{array}{l}\mathrm{HR} \\
0.25(0.13-0.47)\end{array}$ & $\begin{array}{l}\text { BE length, year of BE diagnosis, age at } \\
\text { time of diagnosis, gender and race }\end{array}$ \\
\hline \multirow[t]{2}{*}{$\begin{array}{l}\text { García } \\
\text { Rodríguez } \\
\text { et al. [130] }\end{array}$} & \multirow[t]{2}{*}{2006} & \multirow[t]{2}{*}{$\begin{array}{l}\text { Population- } \\
\text { based nested } \\
\text { case-control } \\
\text { study }\end{array}$} & \multirow[t]{2}{*}{ EAC } & $\begin{array}{l}\text { Current use; within } \\
1 \text { year before the } \\
\text { index date }\end{array}$ & $1.51(0.91-2.50)$ & \multirow[t]{2}{*}{$\begin{array}{l}\text { Age, sex, calendar year, smoking, alcohol } \\
\text { consumption, and body mass index }\end{array}$} \\
\hline & & & & $\begin{array}{l}\text { Past use; the last use } \\
\text { before the index } \\
\text { date }\end{array}$ & $0.81(0.33-1.99)$ & \\
\hline \multirow{2}{*}{$\begin{array}{l}\text { de Jonge } \\
\text { et al. [131] }\end{array}$} & \multirow[t]{2}{*}{2006} & \multirow{2}{*}{$\begin{array}{l}\text { Hospital-based } \\
\text { case-control } \\
\text { study }\end{array}$} & \multirow[t]{2}{*}{ EAC } & $<6$ months & $2.7(0.7-11)$ & \multirow{2}{*}{$\begin{array}{l}\text { Age, gender, educational level, smoking } \\
\text { status, alcohol use, and reflux symptoms }\end{array}$} \\
\hline & & & & $>6$ months & $0.04(0.02-0.09)$ & \\
\hline $\begin{array}{l}\text { Hillman } \\
\text { et al. [129] }\end{array}$ & 2008 & $\begin{array}{l}\text { Retrospective/ } \\
\text { prospective } \\
\text { cohort study }\end{array}$ & $\begin{array}{l}\text { LGD or a } \\
\text { macroscopic } \\
\text { marker }\end{array}$ & After BE diagnosis & $\begin{array}{l}\text { IDR } 3.4 \\
\quad(1.98-5.85)\end{array}$ & Age, gender and year of diagnosis \\
\hline \multirow[t]{2}{*}{$\begin{array}{l}\text { Nguyen } \\
\text { et al. [124] }\end{array}$} & \multirow[t]{2}{*}{2009} & \multirow{2}{*}{$\begin{array}{l}\text { Retrospective } \\
\text { observational } \\
\text { study }\end{array}$} & \multirow[t]{2}{*}{ HGD/EAC } & After BE diagnosis & $\begin{array}{l}\text { HR } 0.39 \\
\quad(0.19-0.80)\end{array}$ & \multirow[t]{2}{*}{ Age, gender and BE length } \\
\hline & & & & $\begin{array}{l}\text { Before or after BE } \\
\text { diagnosis }\end{array}$ & $\begin{array}{l}\text { HR } 0.38 \\
\quad(0.18-0.77)\end{array}$ & \\
\hline $\begin{array}{l}\text { Nguyen } \\
\text { et al. [132] }\end{array}$ & 2010 & $\begin{array}{l}\text { Nested case-- } \\
\text { control study }\end{array}$ & EAC & $\begin{array}{l}\text { After BE diagnosis } \\
\text { and ending } \\
3 \text { months before } \\
\text { the EAC diagnosis }\end{array}$ & $\begin{array}{l}\text { IDR } 1.50 \\
(0.61-3.66)\end{array}$ & $\begin{array}{l}\text { Race, outpatient encounters, noncancer } \\
\text { disease comorbidity index, VA priority } \\
\text { level, and filled prescriptions of NSAID } \\
\text { or statin medication categories }\end{array}$ \\
\hline
\end{tabular}

A macroscopic marker indicates endoscopic finding such as severe esophagitis, stricture, nodularity or Barrett's ulcer

$E A C$ esophageal adenocarcinoma, $H G D$ high-grade dysplasia, $L G D$ low-grade dysplasia, $B E$ Barrett's esophagus, $C I$ confidence intervals, $H R$ hazard ratio, IDR incidence density ratio, VA Veterans' Affairs, NSAID nonsteroidal anti-inflammatory drug

EAC (OR 0.48, $95 \%$ CI 0.32-0.72), and other NSAIDs were also associated with reduced risks of EAC (OR 0.74, $95 \%$ CI 0.51-1.08), particularly among patients with frequent GERD symptoms [142].

In a nested case-control study of individuals with BE, an inverse association was found between filled NSAID/ aspirin prescriptions and EAC, which remained significant when adjusted for PPI prescription, among other factors (incidence density ratio $0.64,95 \%$ CI $0.42-0.97$ ) [132]. Similarly, a recent meta-analysis demonstrated that compared to nonusers, individuals who have used aspirin or nonaspirin NSAIDs had a significantly reduced risk of EAC. The highest levels of frequency (daily or more frequently) and duration ( $\geq 10$ years) of NSAID use were associated with an approximate $40 \%$ reduction in the risk of EAC, with ORs of 0.56 (95\% CI 0.43-0.73, $p=0.001)$ and 0.63 (95\% CI $\left.0.45-0.90, p_{\text {trend }}=0.04\right)$, respectively [143].

In contrast, the 'Chemoprevention for Barrett's Esophagus Trial (CBET)', a phase IIb multicenter trial assessing the efficacy of the selective COX-2 inhibitor celecoxib in patients with $\mathrm{BE}$ showed that the use of celecoxib for 48 weeks did not prevent the progression of BE [144]. Similar results were obtained in a large retrospective study of the UK National Barrett's Oesophagus Registry database, in which no protection from progression to LGD, HGD or EAC was found with the use of aspirin (typically $75 \mathrm{mg} /$ day) [145].

Nguyen et al. [124] showed only a nonsignificant trend toward a lower incidence of HGD or cancer associated with NSAID/aspirin prescriptions. In another study, patients with EAC used NSAIDs/aspirin more frequently compared to the controls (OR 1.8, $95 \%$ CI 1.1-3.2) [131]. In contrast, celecoxib treatment attenuated the incidence of EAC by inhibiting COX-2 expression in an animal model [84]. The possible beneficial role of NSAIDs/aspirin needs to be further examined, with special attention to the progression from BE to cancer.

Falk et al. [146] reported an interesting study in which the combination use of esomeprazole and the short-term administration of higher doses of aspirin, but not lower doses or no aspirin, significantly reduced the tissue concentrations of prostaglandin E2 in patients with BE with either no dysplasia or LGD. These data support the further evaluation of higher doses of aspirin and esomeprazole to prevent EAC in these patients. In addition, a large ongoing clinical trial, the AspECT (Aspirin Esomeprazole Chemoprevention Trial) trial, was designed to evaluate the effects 
of esomeprazole and/or aspirin on the rate of progression to HGD or EAC in patients with BE [147]. This ongoing study may provide an answer to the above questions.

Taken together with previous studies, it is apparent that NSAID intake may be associated with a significant reduction in the risk of EAC, but it remains unclear whether this possible benefit is a result of the reduced risk of $\mathrm{BE}$, reduced risk of cancer in $\mathrm{BE}$, or both.

\section{Ablation therapy for dysplasia and EAC}

To date, endoscopic ablation therapy has been recommended as a strategy to eradicate HGD. A meta-analysis and systematic review by Wani et al. [65] demonstrated that for BE patients who underwent ablative therapies, the weighted-average incidence rates (WIRs) for cancer were $1.63 / 1,000$ pyrs (95 \% CI 0.07-3.34) for nondysplastic BE, $1.58 / 1,000$ pyrs (95 \% CI 0.66-3.84) for LGD, and 16.76/ 1,000 pyrs (95\% CI 10.6-22.9) for HGD patients. In this meta-analysis, the WIR for cancer was higher for nondysplastic BE than for LGD patients undergoing ablation. This most likely represents a statistical aberrancy due to the smaller sample sizes in the LGD studies. In a multicenter, sham-controlled trial, radio frequency ablation was associated with a high rate of complete eradication of both dysplasia and intestinal metaplasia and a reduced risk of disease progression in patients with dysplastic BE [148].

The persistence of underlying SIM (superficial and buried under the neo-squamous epithelium) after ablation is a problem that cannot be ignored. This has been reported in $0-44 \%$ of cases, and the long-term follow-up of successfully treated patients showed recurrence of SIM ranging from 0-68 \% [149]. This is not specific for the type of ablative therapy, and a number of investigators using various modes of ablative therapy have reported this finding [150-156]. Residual SIM carries with it the potential to progress to dysplasia/EAC, but the magnitude of this risk is not well characterized $[155,156]$. Consensus recommendations based on the medical literature that clinicians could use to manage patients with BE and LGD, HGD, or earlystage EAC have been reported [157]. When treating patients with BE-associated dysplasia or EAC, we should consult these evidence-based consensus statements for the management of such patients.

\section{Surveillance of $\mathrm{BE}$ and perspectives}

In an examination of cause-specific mortality in BE patients, the total number of patients died from EAC was small and the remaining died due to other causes, including cardiovascular disease, pulmonary disease and other malignancies [60].
To date, we know of no randomized controlled trials of BE surveillance that have been published; however, several authors have used mathematical models to explore the costeffectiveness of surveillance [158-160]. Despite different modeling approaches and the application of different costs, these studies confirm that the cost-effectiveness of surveillance is crucially dependent on the incidence of EAC. On the basis of costs in the USA, Provenzale et al. [158] concluded that, for a cancer risk of 5 per 1,000 pyrs, surveillance every 4 years was indicated and, if the risk was 0.4 percent per year, surveillance every 5 years was the only strategy to increase a patient's quality of life. With regard to modeling surveillance from a UK perspective, Garside et al. [160] concluded that, at a cancer risk equivalent to 0.5 percent per year, no surveillance costs less and results in a better quality of life than surveillance, irrespective of the surveillance interval used. The estimates of cancer incidence obtained from this systematic review are close to those used in these models and clearly indicate that the cost-effectiveness of Barrett's surveillance is questionable unless it can be targeted to those BE patients who are at the highest risk of cancer. Therefore, this undermines the cost-effectiveness of BE surveillance and supports the search for valid risk stratification tools to identify the minority of patients who are likely to benefit from surveillance $[60,64]$. Hence, surveillance strategies for patients with nondysplastic BE, particularly those with short segments, may need to be reconsidered [66]. In the future, chemoprevention may be needed more than surveillance.

Not everyone with CLE has a similar risk of developing EAC, and much work has been done to identify factors that increase the risk. The risk factors which have been identified are broadly divisible into demographic, pathophysiological, environmental, histopathological and molecular genetics [61].

The question remains as to whether endoscopic surveillance should be recommended in SSBE as well as LSBE. Commonly, the overall incidence rate of colorectal cancers in ulcerative colitis (UC) has been reported to be $3 / 1,000$ pyrs duration (95\% CI 2/1,000-4/1,000) [161]. The cancer incidence rate for SSBE may be higher than the cancer incidence in UC, where surveillance is the norm. Looking at the cancer risk in UC patients from this perspective, it therefore seems unreasonable to exclude these patients from a Barrett's cancer surveillance program.

Conflict of interest The authors declare that they have no conflicts of interest.

\section{References}

1. Cameron AJ. Management of Barrett's esophagus. Mayo Clin Proc. 1998;73:457-61. 
2. Chandrasoma P, Der R, Ma Y, Dalton P, Taira M. Histology of the gastroesophageal junction. Am J Surg Pathol. 2000;24: 402-9.

3. Theisen J, Stein HJ, Dittler HJ, Feith M, Moebius C, Kauer WK, et al. Preoperative chemotherapy unmasks underlying Barrett's mucosa in patients with adenocarcinoma of the distal esophagus. Surg Endosc. 2002;16:671-3.

4. Chandrasoma P, Wickramasinghe K, Ma Y, DeMeester T. Is intestinal metaplasia a necessary precursor lesion for adenocarcinomas of the distal esophagus, gastroesophageal junction and gastric cardia? Dis Esophagus. 2007;20:36-41.

5. Krishnadath KK. Novel findings in the pathogenesis of esophageal columnar metaplasia or Barrett's esophagus. Curr Opin Gastroenterol. 2007;23:440-5.

6. Shaheen NJ. Advances in Barrett's esophagus and esophageal adenocarcinoma. Gastroenterology. 2005;128:1554-66.

7. Conio M, Blanchi S, Lapertosa G, Ferraris R, Sablich R, Marchi $S$, et al. Long-term endoscopic surveillance of patients with Barrett's esophagus: incidence of dysplasia and adenocarcinoma - a prospective study. Am J Gastroenterol. 2003;98: 1931-9.

8. Hameeteman W, Tytgat GN, Houthoff HJ, van den Tweel JG. Barrett's esophagus: development of dysplasia and adenocarcinoma. Gastroenterology. 1989;96:1249-56.

9. Wang KK, Sampliner RE. Updated guidelines 2008 for the diagnosis, surveillance and therapy of Barrett's esophagus. Am J Gastroenterol. 2008;103:788-97.

10. McClave SA, Boyce HW Jr, Gottfried MR. Early diagnosis of columnar-lined esophagus: a new endoscopic diagnostic criterion. Gastrointest Endosc. 1987;33:413-6.

11. Vahabzadeh B, Seetharam AB, Cook MB, Wani S, Rastogi A, Bansal A, et al. Validation of the Prague C \& M criteria for the endoscopic grading of Barrett's esophagus by gastroenterology trainees: a multicenter study. Gastrointest Endosc. 2012; 75:236-41.

12. Sharma P, Dent J, Armstrong D, Bergman JJ, Gossner L, Hoshihara $\mathrm{Y}$, et al. The development and validation of an endoscopic grading system for Barrett's esophagus: the Prague C \& M criteria. Gastroenterology. 2006;131:1392-9.

13. Japanese Classification of Esophageal Cancer. The 10th Edition, Revised version. The Japan Esophageal Society, Kanehara; 2008.

14. Amano Y, Ishimura N, Furuta K, Takahashi Y, Chinuki D, Mishima Y, et al. Which landmark results in a more consistent diagnosis of Barrett's esophagus, the gastric folds or the palisade vessels? Gastrointest Endosc. 2006;64:206-11.

15. Kinjo T, Kusano C, Oda I, Gotoda T. Prague C\&M and Japanese criteria: shades of Barrett's esophagus endoscopic diagnosis. J Gastroenterol. 2010;45:1039-44.

16. Kusano C, Kaltenbach T, Shimazu T, Soetikno R, Gotoda T. Can Western endoscopists identify the end of the lower esophageal palisade vessels as a landmark of esophagogastric junction? J Gastroenterol. 2009;44:842-6.

17. Boyce HW. Endoscopic definitions of esophagogastric junction regional anatomy. Gastrointest Endosc. 2000;51:586-92.

18. Horwhat JD, Baroni D, Maydonovitch C, Osgard E, Ormseth E, Rueda-Pedraza E, et al. Normalization of intestinal metaplasia in the esophagus and esophagogastric junction: incidence and clinical data. Am J Gastroenterol. 2007;102:497-506.

19. Ishimura N, Amano Y, Appelman HD, Penagini R, Tenca A, Falk GW, et al. Barrett's esophagus: endoscopic diagnosis. Ann N Y Acad Sci. 2011;1232:53-75.

20. Chang CY, Lee YC, Lee CT, Tu CH, Hwang JC, Chiang H, et al. The application of Prague $\mathrm{C}$ and $\mathrm{M}$ criteria in the diagnosis of Barrett's esophagus in an ethnic Chinese population. Am J Gastroenterol. 2009;104:13-20.
21. Miwa H, Yokoyama T, Hori K, Sakagami T, Oshima T, Tomita $\mathrm{T}$, et al. Interobserver agreement in endoscopic evaluation of reflux esophagitis using a modified Los Angeles classification incorporating grades $\mathrm{N}$ and $\mathrm{M}$ : a validation study in a cohort of Japanese endoscopists. Dis Esophagus. 2008;21:355-63.

22. Lee YC, Cook MB, Bhatia S, Chow WH, El-Omar EM, Goto H, et al. Interobserver reliability in the endoscopic diagnosis and grading of Barrett's esophagus: an Asian multinational study. Endoscopy. 2010;42:699-704.

23. Ishimura N, Amano Y, Kinoshita Y. Endoscopic definition of esophagogastric junction for diagnosis of Barrett's esophagus: importance of systematic education and training. Dig Endosc. 2009;21:213-8

24. Gudlaugsdottir S, Verschuren W, Dees J, Stijnen T, Wilson J. Hypertension is frequently present in patients with reflux esophagitis or Barrett's esophagus but not in those with nonulcer dyspepsia. Eur J Intern Med. 2002;13:369.

25. Kulig M, Nocon M, Vieth M, Leodolter A, Jaspersen D, Labenz J, et al. Risk factors of gastroesophageal reflux disease: methodology and first epidemiological results of the ProGERD study. J Clin Epidemiol. 2004;57:580-9.

26. Playford RJ. New British Society of Gastroenterology (BSG) guidelines for the diagnosis and management of Barrett's oesophagus. Gut. 2006;55:442.

27. Riddell RH, Odze RD. Definition of Barrett's esophagus: time for a rethink-is intestinal metaplasia dead? Am J Gastroenterol. 2009;104:2588-94.

28. Ogiya K, Kawano T, Ito E, Nakajima Y, Kawada K, Nishikage $\mathrm{T}$, et al. Lower esophageal palisade vessels and the definition of Barrett's esophagus. Dis Esophagus. 2008;21:645-9.

29. Haggitt RC, Tryzelaar J, Ellis FH, Colcher H. Adenocarcinoma complicating columnar epithelium-lined (Barrett's) esophagus. Am J Clin Pathol. 1978;70:1-5.

30. Skinner DB, Walther BC, Riddell RH, Schmidt H, Iascone C, DeMeester TR. Barrett's esophagus. Comparison of benign and malignant cases. Ann Surg. 1983;198:554-65.

31. Smith RR, Hamilton SR, Boitnott JK, Rogers EL. The spectrum of carcinoma arising in Barrett's esophagus. A clinicopathologic study of 26 patients. Am J Surg Pathol. 1984;8:563-73.

32. Rosenberg JC, Budev H, Edwards RC, Singal S, Steiger Z, Sundareson AS. Analysis of adenocarcinoma in Barrett's esophagus utilizing a staging system. Cancer. 1985;55:1353-60.

33. Paraf F, Flejou JF, Pignon JP, Fékété F, Potet F. Surgical pathology of adenocarcinoma arising in Barrett's esophagus. Analysis of 67 cases. Am J Surg Pathol. 1995;19:183-91.

34. Sampliner RE, Practice Parameters Committee of the American College of Gastroenterology. Updated guidelines for the diagnosis, surveillance, and therapy of Barrett's esophagus. Am J Gastroenterol. 2002;97:1888-95.

35. American Gastroenterological Association, Spechler SJ, Sharma P, Souza RF, Inadomi JM, Shaheen NJ. American Gastroenterological Association medical position statement on the management of Barrett's esophagus. Gastroenterology. 2011;140:1084-91.

36. Liu W, Hahn H, Odze RD, Goyal RK. Metaplastic esophageal columnar epithelium without goblet cells shows DNA content abnormalities similar to goblet cell-containing epithelium. Am J Gastroenterol. 2009;104:816-24.

37. Hahn HP, Blount PL, Ayub K, Das KM, Souza R, Spechler S, et al. Intestinal differentiation in metaplastic, nongoblet columnar epithelium in the esophagus. Am J Surg Pathol. 2009;33:1006-15.

38. Takubo K, Aida J, Naomoto Y, Sawabe M, Arai T, Shiraishi H, et al. Cardiac rather than intestinal-type background in endoscopic resection specimens of minute Barrett adenocarcinoma. Hum Pathol. 2009;40:65-74. 
39. Chaves P, Crespo M, Ribeiro C, Laranjeira C, Pereira AD, Suspiro A, et al. Chromosomal analysis of Barrett's cells: demonstration of instability and detection of the metaplastic lineage involved. Mod Pathol. 2007;20:788-96.

40. Gatenby PA, Ramus JR, Caygill CP, Shepherd NA, Watson A. Relevance of the detection of intestinal metaplasia in non-dysplastic columnar-lined oesophagus. Scand J Gastroenterol. 2008;43:524-30.

41. Kelty CJ, Gough MD, Van Wyk Q, Stephenson TJ, Ackroyd R. Barrett's oesophagus: intestinal metaplasia is not essential for cancer risk. Scand J Gastroenterol. 2007;42:1271-4.

42. Vieth M, Barr H. Defining a bad Barrett's segment: is it dependent on goblet cells? Am J Gastroenterol. 2009;104: $825-7$.

43. Bhat S, Coleman HG, Yousef F, Johnston BT, McManus DT, Gavin AT, et al. Risk of malignant progression in Barrett's esophagus patients: results from a large population-based study. J Natl Cancer Inst. 2011;103:1049-57.

44. Shaheen NJ, Crosby MA, Bozymski EM, Sandler RS. Is there publication bias in the reporting of cancer risk in Barrett's esophagus? Gastroenterology. 2000;119:333-8.

45. American Gastroenterological Association Technical Review on the Management of Barrett's Esophagus. Gastroenterology. 2011;140:e18-52.

46. Blot WJ, Devesa SS, Kneller RW, Fraumeni JF Jr. Rising incidence of adenocarcinoma of the esophagus and gastric cardia. JAMA. 1991;265:1287-9.

47. Devesa SS, Blot WJ, Fraumeni JF Jr. Changing patterns in the incidence of esophageal and gastric carcinoma in the United States. Cancer. 1998;83:2049-53.

48. van Soest EM, Dieleman JP, Siersema PD, Sturkenboom MC, Kuipers EJ. Increasing incidence of Barrett's oesophagus in the general population. Gut. 2005;54:1062-6.

49. Ho KY. Gastroesophageal reflux disease in Asia: a condition in evolution. J Gastroenterol Hepatol. 2008;23:716-22.

50. Wu JC. Gastroesophageal reflux disease: an Asian perspective. J Gastroenterol Hepatol. 2008;23:1785-93.

51. Fujiwara Y, Arakawa T. Epidemiology and clinical characteristics of GERD in the Japanese population. J Gastroenterol. 2009;44:518-34.

52. Goh KL. Gastroesophageal reflux disease in Asia: a historical perspective and present challenges. J Gastroenterol Hepatol. 2011;26(Suppl 1):2-10.

53. Kim KM, Cho YK, Bae SJ, Kim DS, Shim KN, Kim JH, et al. Prevalence of gastroesophageal reflux disease in Korea and associated health-care utilization: a national population-based study. J Gastroenterol Hepatol. 2012;27:741-5.

54. Lu CL, Lang HC, Luo JC, Liu CC, Lin HC, Chang FY, et al. Increasing trend of the incidence of esophageal squamous cell carcinoma, but not adenocarcinoma, in Taiwan. Cancer Causes Control. 2010;21:269-74.

55. Fernandes M, Seow A, Chan YH, Ho KY. Opposing trends in incidence of esophageal squamous cell carcinoma and adenocarcinoma in a multi-ethnic Asian country. Am J Gastroenterol. 2006;101:1430-6.

56. Yee YK, Cheung TK, Chan AO, Yuen MF, Wong BC. Decreasing trend of esophageal adenocarcinoma in Hong Kong. Cancer Epidemiol Biomarkers Prev. 2007;16:2637-40.

57. Shibata A, Matsuda T, Ajiki W, Sobue T. Trend in incidence of adenocarcinoma of the esophagus in Japan, 1993-2001. Jpn J Clin Oncol. 2008;38:464-8.

58. Cameron AJ, Ott BJ, Payne WS. The incidence of adenocarcinoma in columnar-lined (Barrett's) esophagus. N Engl J Med. 1985;313:857-9.

59. Aldulaimi DM, Nwokolo CU, Loft DE. Barrett's surveillance is worthwhile and detects curable cancers. A prospective cohort study addressing cancer incidence, treatment outcome and survival. Eur J Gastroenterol Hepatol. 2005;17:943-50.

60. Sikkema M, de Jonge PJ, Steyerberg EW, Kuipers EJ. Risk of esophageal adenocarcinoma and mortality in patients with Barrett's esophagus: a systematic review and meta-analysis. Clin Gastroenterol Hepatol. 2010;8:235-44.

61. Caygill CP, Watson A, Lao-Sirieix P, Fitzgerald RC. Barrett's oesophagus and adenocarcinoma. World J Surg Oncol. 2004;2:12.

62. Chang EY, Morris CD, Seltman AK, O'Rourke RW, Chan BK, Hunter JG, et al. The effect of antireflux surgery on esophageal carcinogenesis in patients with Barrett esophagus: a systematic review. Ann Surg. 2007;246:11-21.

63. Thomas T, Abrams KR, De Caestecker JS, Robinson RJ. Meta analysis: cancer risk in Barrett's oesophagus. Aliment Pharmacol Ther. 2007;26:1465-77.

64. Yousef F, Cardwell C, Cantwell MM, Galway K, Johnston BT, Murray L. The incidence of esophageal cancer and high-grade dysplasia in Barrett's esophagus: a systematic review and metaanalysis. Am J Epidemiol. 2008;168:237-49.

65. Wani S, Puli SR, Shaheen NJ, Westhoff B, Slehria S, Bansal A, et al. Esophageal adenocarcinoma in Barrett's esophagus after endoscopic ablative therapy: a meta-analysis and systematic review. Am J Gastroenterol. 2009;104:502-13.

66. Desai TK, Krishnan K, Samala N, Singh J, Cluley J, Perla S, et al. The incidence of oesophageal adenocarcinoma in non-dysplastic Barrett's oesophagus: a meta-analysis. Gut. 2012;61:970-6.

67. de Jonge PJ, van Blankenstein M, Looman CW, Casparie MK, Meijer GA, Kuipers EJ. Risk of malignant progression in patients with Barrett's oesophagus: a Dutch nationwide cohort study. Gut. 2010;59:1030-6.

68. Hvid-Jensen F, Pedersen L, Drewes AM, Sørensen HT, FunchJensen P. Incidence of adenocarcinoma among patients with Barrett's esophagus. N Engl J Med. 2011;365:1375-83.

69. Jankowski JA, Provenzale D, Moayyedi P. Esophageal adenocarcinoma arising from Barrett's metaplasia has regional variations in the west. Gastroenterology. 2002;122:588-90.

70. Miros M, Kerlin P, Walker N. Only patients with dysplasia progress to adenocarcinoma in Barrett's oesophagus. Gut. 1991;32:1441-6.

71. Williamson WA, Ellis FH Jr, Gibb SP, Shahian DM, Aretz HT, Heatley GJ, et al. Barrett's esophagus. Prevalence and incidence of adenocarcinoma. Arch Intern Med. 1991;151:2212-6.

72. van der Burgh A, Dees J, Hop WC, van Blankenstein M. Oesophageal cancer is an uncommon cause of death in patients with Barrett's oesophagus. Gut. 1996;39:5-8.

73. Avidan B, Sonnenberg A, Schnell TG, Chejfec G, Metz A, Sontag SJ. Hiatal hernia size, Barrett's length, and severity of acid reflux are all risk factors for esophageal adenocarcinoma. Am J Gastroenterol. 2002;97:1930-6.

74. Weston AP, Badr AS, Hassanein RS. Prospective multivariate analysis of clinical, endoscopic, and histological factors predictive of the development of Barrett's multifocal high-grade dysplasia or adenocarcinoma. Am J Gastroenterol. 1999;94: 3413-9.

75. Levine DS, Haggitt RC, Blount PL, Rabinovitch PS, Rusch VW, Reid BJ. An endoscopic biopsy protocol can differentiate highgrade dysplasia from early adenocarcinoma in Barrett's esophagus. Gastroenterology. 1993;105:40-50.

76. Hamilton SR, Smith RR, Cameron JL. Prevalence and characteristics of Barrett esophagus in patients with adenocarcinoma of the esophagus or esophagogastric junction. Hum Pathol. 1988;19:942-8.

77. Schnell TG, Sontag SJ, Chejfec G. Adenocarcinomas arising in tongues or short segments of Barrett's esophagus. Dig Dis Sci. 1992;37:137-43. 
78. Cameron AJ, Lomboy CT, Pera M, Carpenter HA. Adenocarcinoma of the esophagogastric junction and Barrett's esophagus. Gastroenterology. 1995;109:1541-6.

79. Sharma P, Morales TG, Bhattacharyya A, Garewal HS, Sampliner RE. Dysplasia in short-segment Barrett's esophagus: a prospective 3-year followup. Am J Gastroenterol. 1997;92: 2012-6.

80. Iftikhar SY, James PD, Steele RJ, Hardcastle JD, Atkinson M. Length of Barrett's oesophagus: an important factor in the development of dysplasia and adenocarcinoma. Gut. 1992;33: 1155-8.

81. Rudolph RE, Vaughan TL, Storer BE, Haggitt RC, Rabinovitch PS, Levine DS, et al. Effect of segment length on risk for neoplastic progression in patients with Barrett esophagus. Ann Intern Med. 2000;132:612-20.

82. Anaparthy R, Gaddam S, Kanakadandi V, Alsop BR, Gupta N, Higbee AD, et al. Association between length of Barrett's esophagus and risk of high-grade dysplasia or adenocarcinoma in patients without dysplasia. Clin Gastroenterol Hepatol. 2013 (Epub ahead of print).

83. Rokkas T, Pistiolas D, Sechopoulos P, Robotis I, Margantinis G. Relationship between Helicobacter pylori infection and esophageal neoplasia: a meta-analysis. Clin Gastroenterol Hepatol. 2007;5:1413-7.

84. Liu FX, Wang WH, Wang J, Li J, Gao PP. Effect of Helicobacter pylori infection on Barrett's esophagus and esophageal adenocarcinoma formation in a rat model of chronic gastroesophageal reflux. Helicobacter. 2011;16:66-77.

85. Fischbach LA, Nordenstedt H, Kramer JR, Gandhi S, DickOnuoha S, Lewis A, et al. The association between Barrett's esophagus and Helicobacter pylori infection: a meta-analysis. Helicobacter. 2012;17:163-75.

86. Wang C, Yuan Y, Hunt RH. Helicobacter pylori infection and Barrett's esophagus: a systematic review and meta-analysis. Am J Gastroenterol. 2009;104:492-500.

87. Thrift AP, Pandeya N, Smith KJ, Green AC, Hayward NK, Webb PM, et al. Helicobacter pylori infection and the risks of Barrett's oesophagus: a population-based case-control study. Int J Cancer. 2012;130:2407-16.

88. Kountouras J, Chatzopoulos D, Zavos C, Polyzos SA, GiartzaTaxidou E, Vardaka E, et al. Helicobacter pylori infection might contribute to esophageal adenocarcinoma progress in subpopulations with gastroesophageal reflux disease and Barrett's esophagus. Helicobacter. 2012;17:402-3.

89. Rajendra S, Robertson IK. Ethnicity, GORD, Barrett's oesophagus and Helicobacter pylori infection. Gut. 2008;57:1738-9.

90. Abe Y, Ohara S, Koike T, Sekine H, Iijima K, Kawamura M, et al. The prevalence of Helicobacter pylori infection and the status of gastric acid secretion in patients with Barrett's esophagus in Japan. Am J Gastroenterol. 2004;99:1213-21.

91. Inomata Y, Koike T, Ohara S, Abe Y, Sekine H, Iijima K, et al. Preservation of gastric acid secretion may be important for the development of gastroesophageal junction adenocarcinoma in Japanese people, irrespective of the $H$. pylori infection status. Am J Gastroenterol. 2006;101:926-33.

92. El-Serag HB, Mason AC, Petersen N, Key CR. Epidemiological differences between adenocarcinoma of the oesophagus and adenocarcinoma of the gastric cardia in the USA. Gut. 2002:50:368-72.

93. Horii T, Koike T, Abe Y, Kikuchi R, Unakami H, Iijima K, et al. Two distinct types of cancer of different origin may be mixed in gastroesophageal junction adenocarcinomas in Japan: evidence from direct evaluation of gastric acid secretion. Scand J Gastroenterol. 2011;46:710-9.

94. Nakajima S, Hattori T. Oesophageal adenocarcinoma or gastric cancer with or without eradication of Helicobacter pylori infection in chronic atrophic gastritis patients: a hypothetical opinion from a systematic review. Aliment Pharmacol Ther. 2004;20(Suppl 1):54-61.

95. El-Serag H. The association between obesity and GERD: a review of the epidemiological evidence. Dig Dis Sci. 2008;53:2307-12.

96. Hampel H, Abraham NS, El-Serag HB. Meta-analysis: obesity and the risk for gastroesophageal reflux disease and its complications. Ann Intern Med. 2005;143:199-211.

97. El-Serag HB, Ergun GA, Pandolfino J, Fitzgerald S, Tran T, Kramer JR. Obesity increases oesophageal acid exposure. Gut. 2007;56:749-55.

98. Corley DA, Kubo A, Levin TR, Block G, Habel L, Zhao W, et al. Abdominal obesity and body mass index as risk factors for Barrett's esophagus. Gastroenterology. 2007;133:34-41.

99. Edelstein ZR, Farrow DC, Bronner MP, Rosen SN, Vaughan TL. Central adiposity and risk of Barrett's esophagus. Gastroenterology. 2007;133:403-11.

100. El-Serag HB, Kvapil P, Hacken-Bitar J, Kramer JR. Abdominal obesity and the risk of Barrett's esophagus. Am J Gastroenterol. 2005;100:2151-6.

101. Akiyama T, Yoneda M, Inamori M, Iida H, Endo H, Hosono K, et al. Visceral obesity and the risk of Barrett's esophagus in Japanese patients with non-alcoholic fatty liver disease. BMC Gastroenterol. 2009;9:56.

102. Ford ES, Mokdad AH, Giles WH. Trends in waist circumference among U.S. adults. Obes Res. 2003;11:1223-31.

103. Corley DA, Kubo A, Zhao W. Abdominal obesity, ethnicity and gastro-oesophageal reflux symptoms. Gut. 2007;56:756-62.

104. El-Serag HB, Petersen NJ, Carter J, Graham DY, Richardson P, Genta RM, et al. Gastroesophageal reflux among different racial groups in the United States. Gastroenterology. 2004;126: 1692-9.

105. Spechler SJ, Jain SK, Tendler DA, Parker RA. Racial differences in the frequency of symptoms and complications of gastro-oesophageal reflux disease. Aliment Pharmacol Ther. 2002;16:1795-800.

106. Brown LM, Swanson CA, Gridley G, Swanson GM, Schoenberg JB, Greenberg RS, et al. Adenocarcinoma of the esophagus: role of obesity and diet. J Natl Cancer Inst. 1995;87:104-9.

107. Vaughan TL, Davis S, Kristal A, Thomas DB. Obesity, alcohol, and tobacco as risk factors for cancers of the esophagus and gastric cardia: adenocarcinoma versus squamous cell carcinoma. Cancer Epidemiol Biomarkers Prev. 1995;4:85-92.

108. Chow WH, Blot WJ, Vaughan TL, Risch HA, Gammon MD, Stanford JL, et al. Body mass index and risk of adenocarcinomas of the esophagus and gastric cardia. J Natl Cancer Inst. 1998;90:150-5.

109. Lagergren J, Bergström R, Nyrén O. Association between body mass and adenocarcinoma of the esophagus and gastric cardia. Ann Intern Med. 1999;130:883-90.

110. Wu AH, Wan P, Bernstein L. A multiethnic population-based study of smoking, alcohol and body size and risk of adenocarcinomas of the stomach and esophagus (United States). Cancer Causes Control. 2001;12:721-32.

111. Blot WJ, McLaughlin JK. The changing epidemiology of esophageal cancer. Semin Oncol. 1999;26:2-8.

112. Engeland A, Tretli S, Bjørge T. Height and body mass index in relation to esophageal cancer; 23-year follow-up of two million Norwegian men and women. Cancer Causes Control. 2004;15: 837-43.

113. Lindblad M, Rodríguez LA, Lagergren J. Body mass, tobacco and alcohol and risk of esophageal, gastric cardia, and gastric non-cardia adenocarcinoma among men and women in a nested case-control study. Cancer Causes Control. 2005;16: 285-94. 
114. Samanic C, Chow WH, Gridley G, Jarvholm B, Fraumeni JF Jr. Relation of body mass index to cancer risk in 362,552 Swedish men. Cancer Causes Control. 2006;17:901-9.

115. Abnet CC, Freedman ND, Hollenbeck AR, Fraumeni JF Jr, Leitzmann M, Schatzkin A. A prospective study of BMI and risk of oesophageal and gastric adenocarcinoma. Eur $\mathrm{J}$ Cancer. 2008;44:465-71.

116. Anderson LA, Watson RG, Murphy SJ, Johnston BT, Comber $\mathrm{H}, \mathrm{Mc}$ Guigan J, et al. Risk factors for Barrett's oesophagus and oesophageal adenocarcinoma: results from the FINBAR study. World J Gastroenterol. 2007;13:1585-94.

117. Engel LS, Chow WH, Vaughan TL, Gammon MD, Risch HA, Stanford JL, et al. Population attributable risks of esophageal and gastric cancers. J Natl Cancer Inst. 2003;95:1404-13.

118. Kubo A, Corley DA. Body mass index and adenocarcinomas of the esophagus or gastric cardia: a systematic review and metaanalysis. Cancer Epidemiol Biomarkers Prev. 2006;15:872-8.

119. Spechler SJ. Dysplasia in Barrett's esophagus: limitations of current management strategies. Am J Gastroenterol. 2005;100: 927-35.

120. Kauer WK, Peters JH, DeMeester TR, Ireland AP, Bremner CG, Hagen JA. Mixed reflux of gastric and duodenal juices is more harmful to the esophagus than gastric juice alone: the need for surgical therapy re-emphasized. Ann Surg. 1995;222:525-31 (discussion 531-3).

121. Peters FT, Ganesh S, Kuipers EJ, Sluiter WJ, Klinkenberg-Knol EC, Lamers CB, et al. Endoscopic regression of Barrett's oesophagus during omeprazole treatment; a randomised double blind study. Gut. 1999;45:489-94.

122. El-Serag HB, Aguirre TV, Davis S, Kuebeler M, Bhattacharyya A, Sampliner RE. Proton pump inhibitors are associated with reduced incidence of dysplasia in Barrett's esophagus. Am J Gastroenterol. 2004;99:1877-83.

123. Hillman LC, Chiragakis L, Shadbolt B, Kaye GL, Kaye GL, Clarke AC. Proton pump inhibitor therapy and the development of dysplasia in patients with Barrett's oesophagus. Med J Aust. 2004; 180:387-91.

124. Nguyen DM, El-Serag HB, Henderson L, Stein D, Bhattacharyya A, Sampliner RE. Medication usage and the risk of neoplasia in patients with Barrett's esophagus. Clin Gastroenterol Hepatol. 2009;7:1299-304.

125. Gore S, Healey CJ, Sutton R, Eyre-Brook IA, Gear MW, Shepherd NA, et al. Regression of columnar lined (Barrett's) oesophagus with continuous omeprazole therapy. Aliment Pharmacol Ther. 1993;7:623-8.

126. Sampliner RE. Effect of up to 3 years of high-dose lansoprazole on Barrett's esophagus. Am J Gastroenterol. 1994;89:1844-8.

127. Sharma P, Sampliner RE, Camargo E. Normalization of esophageal $\mathrm{pH}$ with high-dose proton pump inhibitor therapy does not result in regression of Barrett's esophagus. Am J Gastroenterol. 1997;92:582-5.

128. Cooper BT, Neumann CS, Cox MA, Iqbal TH. Continuous treatment with omeprazole $20 \mathrm{mg}$ daily for up to 6 years in Barrett's oesophagus. Aliment Pharmacol Ther. 1998;12:893-7.

129. Hillman LC, Chiragakis L, Shadbolt B, Kaye GL, Clarke AC. Effect of proton pump inhibitors on markers of risk for highgrade dysplasia and oesophageal cancer in Barrett's oesophagus. Aliment Pharmacol Ther. 2008;27:321-6.

130. García Rodríguez LA, Lagergren J, Lindblad M. Gastric acid suppression and risk of oesophageal and gastric adenocarcinoma: a nested case control study in the UK. Gut. 2006;55:1538-44.

131. de Jonge PJ, Steyerberg EW, Kuipers EJ, Honkoop P, Wolters LM, Kerkhof M, et al. Risk factors for the development of esophageal adenocarcinoma in Barrett's esophagus. Am J Gastroenterol. 2006;101:1421-9.
132. Nguyen DM, Richardson P, El-Serag HB. Medications (NSAIDs, statins, proton pump inhibitors) and the risk of esophageal adenocarcinoma in patients with Barrett's esophagus. Gastroenterology. 2010;138:2260-6.

133. Islami F, Kamangar F, Boffetta P. Use of proton pump inhibitors and risk of progression of Barrett's esophagus to neoplastic lesions. Am J Gastroenterol. 2009;104:2646-8.

134. Leedham S, Jankowski J. The evidence base of proton pump inhibitor chemopreventative agents in Barrett's esophagus-the good, the bad, and the flawed! Am J Gastroenterol. 2007;102:21-3.

135. Cooper BT, Chapman W, Neumann CS, Gearty JC. Continuous treatment of Barrett's oesophagus patients with proton pump inhibitors up to 13 years: observations on regression and cancer incidence. Aliment Pharmacol Ther. 2006;23:727-33.

136. Ouatu-Lascar R, Fitzgerald RC, Triadafilopoulos G. Differentiation and proliferation in Barrett's esophagus and the effects of acid suppression. Gastroenterology. 1999;117:327-35.

137. Peters FT, Ganesh S, Kuipers EJ, Sluiter WJ, Karrenbeld A, de Jager-Krikken A, et al. Effect of elimination of acid reflux on epithelial cell proliferative activity of Barrett esophagus. Scand J Gastroenterol. 2000;35:1238-44.

138. Umansky M, Yasui W, Hallak A, Brill S, Shapira I, Halpern Z, et al. Proton pump inhibitors reduce cell cycle abnormalities in Barrett's esophagus. Oncogene. 2001;20:7987-91.

139. Corley DA, Kerlikowske K, Verma R, Buffler P. Protective association of aspirin/NSAIDs and esophageal cancer: a systematic review and meta-analysis. Gastroenterology. 2003;124: $47-56$.

140. Vaughan TL, Dong LM, Blount PL, Ayub K, Odze RD, Sanchez $\mathrm{CA}$, et al. Non-steroidal anti-inflammatory drugs and risk of neoplastic progression in Barrett's oesophagus: a prospective study. Lancet Oncol. 2005;6:945-52.

141. Kastelein F, Spaander MC, Biermann K, Steyerberg EW, Kuipers EJ, Bruno MJ. Nonsteroidal anti-inflammatory drugs and statins have chemopreventative effects in patients with Barrett's esophagus. Gastroenterology. 2011;141:2000-8.

142. Sadeghi S, Bain CJ, Pandeya N, Webb PM, Green AC, Whiteman DC, Australian Cancer Study. Aspirin, nonsteroidal antiinflammatory drugs, and the risks of cancers of the esophagus. Cancer Epidemiol Biomarkers Prev. 2008;17:1169-78.

143. Liao LM, Vaughan TL, Corley DA, Cook MB, Casson AG, Kamangar F, et al. Nonsteroidal anti-inflammatory drug use reduces risk of adenocarcinomas of the esophagus and esophagogastric junction in a pooled analysis. Gastroenterology. 2012;142:442-52.

144. Heath EI, Canto MI, Piantadosi S, Montgomery E, Weinstein WM, Herman JG, Chemoprevention for Barrett's Esophagus Trial Research Group, et al. Secondary chemoprevention of Barrett's esophagus with celecoxib: results of a randomized trial. J Natl Cancer Inst. 2007;99:545-57.

145. Gatenby PA, Ramus JR, Caygill CP, Winslet MC, Watson A. Aspirin is not chemoprotective for Barrett's adenocarcinoma of the oesophagus in multicentre cohort. Eur $\mathrm{J}$ Cancer Prev. 2009; $18: 381-4$

146. Falk GW, Buttar NS, Foster NR, Ziegler KL, Demars CJ, Romero Y, Cancer Prevention Network, et al. A combination of esomeprazole and aspirin reduces tissue concentrations of prostaglandin $\mathrm{E}(2)$ in patients with Barrett's esophagus. Gastroenterology. 2012;143:917-26.

147. Das D, Chilton AP, Jankowski JA. Chemoprevention of oesophageal cancer and the AspECT trial. Recent Results Cancer Res. 2009;181:161-9.

148. Shaheen NJ, Sharma P, Overholt BF, Wolfsen HC, Sampliner RE, Wang KK, et al. Radiofrequency ablation in Barrett's esophagus with dysplasia. N Engl J Med. 2009;360:2277-88. 
149. Yeh RW, Triadalfilopoulos G. Endoscopic therapy for Barrett's esophagus. Gastrointest Endosc Clin N Am. 2005;15:377-97 vii.

150. Van Laethem JL, Cremer M, Peny MO, Delhaye M, Devière J. Eradication of Barrett's mucosa with argon plasma coagulation and acid suppression: immediate and mid term results. Gut. 1998;43:747-51.

151. Sharma P, Bhattacharyya A, Garewal HS, Sampliner RE. Durability of new squamous epithelium after endoscopic reversal of Barrett's esophagus. Gastrointest Endosc. 1999;50: $159-64$.

152. Kovacs BJ, Chen YK, Lewis TD, DeGuzman LJ, Thompson KS. Successful reversal of Barrett's esophagus with multipolar electrocoagulation despite inadequate acid suppression. Gastrointest Endosc. 1999;49:547-53.

153. Sampliner RE, Faigel D, Fennerty MB, Lieberman D, Ippoliti A, Lewin $\mathrm{K}$, et al. Effective and safe endoscopic reversal of nondysplastic Barrett's esophagus with thermal electrocoagulation combined with high-dose acid inhibition: a multicenter study. Gastrointest Endosc. 2001;53:554-8.

154. Overholt BF, Panjehpour M, Haydek J. Photodynamic therapy for Barrett's esophagus: follow-up in 100 patients. Gastrointest Endosc. 1999;49:1-7.

155. Shand A, Dallal H, Palmer K, Ghosh S, MacIntyre M. Adenocarcinoma arising in columnar lined oesophagus following treatment with argon plasma coagulation. Gut. 2001;48:580-1.
156. Van Laethem JL, Peny MO, Salmon I, Cremer M, Devière J. Intramucosal adenocarcinoma arising under squamous re-epithelialisation of Barrett's oesophagus. Gut. 2000;46:574-7.

157. Bennett C, Vakil N, Bergman J, Harrison R, Odze R, Vieth M, et al. Consensus statements for management of Barrett's dysplasia and early-stage esophageal adenocarcinoma, based on a Delphi process. Gastroenterology. 2012;143:336-46.

158. Provenzale D, Schmitt C, Wong JB. Barrett's esophagus: a new look at surveillance based on emerging estimates of cancer risk. Am J Gastroenterol. 1999;94:2043-53.

159. Inadomi JM, Sampliner R, Lagergren J, Lieberman D, Fendrick AM, Vakil N. Screening and surveillance for Barrett esophagus in high-risk groups: a cost-utility analysis. Ann Intern Med. 2003;138:176-86.

160. Garside R, Pitt M, Somerville M, Stein K, Price A, Gilbert N. Surveillance of Barrett's oesophagus: exploring the uncertainty through systematic review, expert workshop and economic modelling. Health Technol Assess. 2006;10:1-142, iii-iv.

161. Eaden JA, Abrams KR, Mayberry JF. The risk in ulcerative colitis: a meta-analysis. Gut. 2001;48:526-35. 